\title{
ANALISIS DAN STRATEGI UNTUK MENDUKUNG PROSPEK PERDAGANGAN RUMPUT LAUT INDONESIA
}

\section{An Analysis and Strategy For Supporting Indonesian Seaweed Trade Prospects}

\author{
Rahmadini Payla Juarsa \\ Program Pascasarjana Teknik Industri Pertanian, IPB University \\ J. Raya Darmaga, Kampus IPB Darmaga, Bogor, Jawa Barat 16680
}

\begin{abstract}
The Indonesian seaweed trade is still dominated by dry seaweed, even though Indonesia's seaweed still has high prospects for development. The purpose of this study is to analyze and provide strategies for supporting the prospects of Indonesia's seaweed trade. In achieving this goal, we use qualitative desk study methods and SWOT analysis. The results showed that Indonesia's seaweed trade still shows the opportunity to increase high added value by prioritizing the trade of semi-finished products rather than dried seaweed. This is supported by the strength of Indonesian seaweed which has a large potential for cultivation, a high number of laborer, high consumption of domestic and foreign seaweed derivative products and the availability of sufficient technology and expertise. Those strengths used to seize high import market opportunities. The existence of a national seaweed development road map also helps create a better prospect for seaweed trade.
\end{abstract}

Keywords: Indonesian seaweed, trade prospects, SWOT analysis

\begin{abstract}
ABSTRAK: Perdagangan rumput laut Indonesia masih hingga kini masih didominasi oleh rumput laut kering, padahal rumput laut Indonesia masih memiliki prospek tinggi untuk dikembangkan. Tujuan penelitian ini adalah menganalisis dan memberikan strategi untuk mendukung prospek perdagangan rumput laut Indonesia. Dalam mencapai tujuan tersebut, kami menggunakan metode desk study kualitatif dan dan analisis SWOT. Hasil penelitian menunjukkan bahwa perdagangan rumput laut Indonesia masih menujukkan peluang peningkatan nilai tambah yang tinggi dengan mengutamakan perdagangan produk setengah jadi daripada rumput laut kering. Hal ini didukung oleh kekuatan rumput laut Indonesia yang memiliki potensi budidaya yang besar, jumlah angka kerja tinggi, konsumsi produk turunan rumput laut dalam dan luar negeri tinggi dan ketersediaan teknologi serta tenaga ahli yang cukup. Kekuatan ini dapat digunakan untuk mengambil peluang pasar impor yang tinggi. Adanya road map pengembangan rumput laut Nasional juga membantu menciptakan prospek perdagangan rumput laut menjadi lebih baik.
\end{abstract}

Kata kunci : rumput laut Indonesia, prospek perdagangan, analisis SWOT

\section{PENDAHULUAN}

Prospek perdagangan rumput laut Indonesia merujuk pada gambaran pasar rumput laut masa mendatang. Perdagangan rumput laut di Indonesia hingga saat ini masih didominasi oleh perdagangan bahan baku mentah. Tahun 2018 tercatat sebanyak $201.161 .773 \mathrm{~kg}$ rumput laut kering diekspor dari Indonesia (BPS 2018). Di tahun yang sama ekspor agar-agar dan karaginan yang merupakan produk turunan antara rumput laut masingmasing hanya sebesar $1.488 .871 \mathrm{~kg}$ dan $10.310 .881 \mathrm{~kg}$. Hal ini berarti 94\% ekspor rumput laut Indonesia masih merupakan bahan baku mentah (Gambar 1). Negara tujuan utama ekspor rumput laut Indonesia ini adalah China, Amerika Serikat, dan Korea Selatan (Gambar 2).

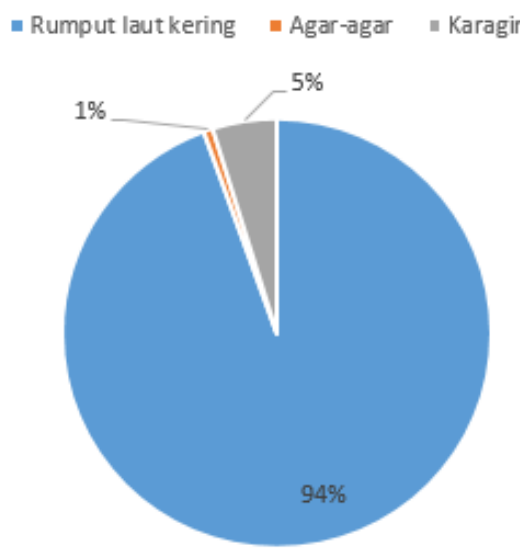




\section{Gambar 1. Jenis produk ekspor rumput} laut Indonesia

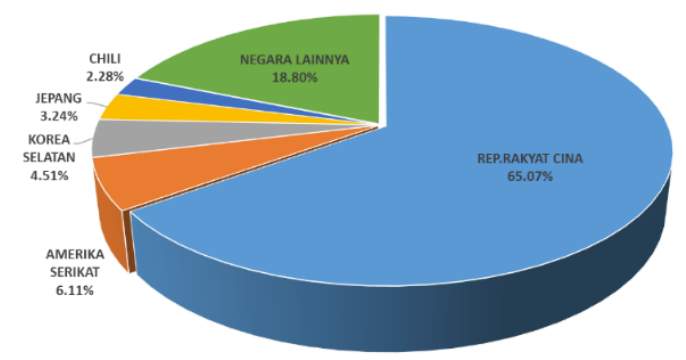

\section{Gambar 2. Persebaran ekspor rumput laut Indonesia}

Rumput laut kering tidak memiliki nilai tambah yang besar dalam rantai nilai industri rumput laut. Padahal jika diolah lebih lanjut, banyak sekali produk turunan dari rumput laut ini yang menghasilkan nilai tambah lebih tinggi. Produk turunan tersebut seperti ATC (alkali treated cottonii), ATG (alkali treated gracilaria), ATCC (alkali treated cottonii chips), agaragar, karaginan, produk kosmetik, pasta gigi, minuman jeli, produk berupa bubuk (susu, minumam bubuk) dan masih banyak lagi produk lainnya. Kurangnya pembuatan produk turunan ini disebabkan oleh banyak hal, di antaranya adalah pendekatan tidak terintegrasi, kurangnnya inovasi pelaku usaha, kurangnya pengenalan dan pendalaman produk unggulan, kurangnya permodalan, lemahnya kelembagaan dan permasalahan pemasaran (Hikmah 2015).

Faktanya, menurut Kementerian Perdagangan (Kemendag) RI , 81\% permintaan ekspor dunia adalah barang manufaktur sedangkan $19 \%$ sisanya adalah bahan mentah. Walaupun menurut Permendag 13/2012 Tentang Ketentuan Umum dibidang Ekspor, rumput laut menjadi komoditas bebas ekspor, Pemerintah mulai merencanakan untuk mengurangi ekspor bahan baku rumput laut kering agar industri dalam negeri lebih banyak menghasilkan produk bernilai tambah tinggi untuk diekspor. Diharapkan dengan mengekspor produk turunan rumput laut, pendapatan negara akan lebih bertambah.

Menurut Peraturan Presiden (Perpres) Nomor 33 Tahun 2019 tentang
Peta Panduan (Road Map)

Pengembangan Industri Rumput Laut Nasional Tahun 2018-2021, terdapat lebih kurang 140 negara pengimpor rumput laut pada tahun 2016 yang dikelompokkan menurut kode HS yang dijelaskan pada Tabel 1 dan Gambar 3. Dari data tersebut terlihat bahwa impor dunia paling banyak terdapat pada rumput laut kering. Hal ini tentunya potensi pasar bagi Indonesia untuk tidak mengekspor terlalu banyak rumput laut kering dan mengolahnya menjadi produk setengah jadi atau produk turunan lainnya. Hal ini melihat impor dunia akan bahan baku tentu menjadi input bagi bahan baku industri mereka di negara asalnya. Idenya adalah bahwa Indonesia bisa memanfaatkan ini sebagai peluang untuk bersaing di pasar produk hilir dengan potensi bahan baku yang dimiliki lebih banyak.

Tabel 1. Negera pengimpor rumput laut dunia

\begin{tabular}{|c|l|l|}
\hline Kode HS & \multicolumn{1}{|c|}{ Keterangan } & \multicolumn{1}{|c|}{$\begin{array}{c}\text { Negara } \\
\text { Pengimpor } \\
\text { Utama }\end{array}$} \\
\hline 1212.21 & Rumput Laut atau & China \\
& Ganggang Lainnya: & $(56,95 \%)$, \\
& Jepang \\
& Manusia & $(13,55 \%)$ dan \\
& & Taipei \\
& & $(6,33 \%)$ \\
\hline 1212.29 & Rumput Laut atau & China \\
& Ganggang Lainnya: & $(44,38 \%)$, \\
& Tidak Dikonsumsi & Irlandia \\
& Manusia & $(19,58)$ dan \\
& & Prancis \\
& & $(7,50 \%)$ \\
\hline 1302.31 & Agar-agar & Jepang \\
& & $(13,57 \%)$, \\
& & Amerika \\
& & Serikat \\
& & $(10,75 \%)$, \\
& & dan Spanyol \\
& & $(7,55 \%)$ \\
\hline 1302.39 & Karaginan & Amerika \\
& & Serikat \\
& & $(32,75 \%)$, \\
& & Meksiko \\
& & $(22,62 \%)$ dan \\
& & Filipina \\
& & $(7,61 \%)$ \\
\hline
\end{tabular}




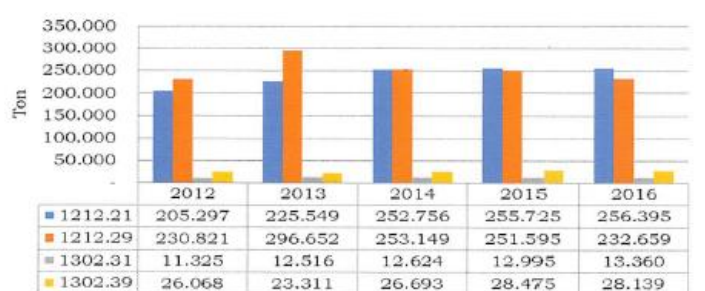

Gambar 3. Volume impor rumput laut dunia tahun 2012-2016

Potensi budidaya rumput laut di Indonesia bolehlah dikatakan besar. Hal ini karena Indonesia memiliki luas lautan sebesar 6,4 juta km2 dan memiliki potensi areal budidaya rumput laut laut sebesar 1,43 juta ha. Namun faktanya luasan ini yang telah dimanfaatkan menjadi wilayah budidaya rumput laut sampai dengan tahun 2017 sekitar 18,76\% (sekitar 267.800 ha) (KKP RI 2017).

Berdasarkan fakta-fakta yang dikemukakan di atas, maka penelitian ini bertujuan untuk menganalisis dan menetapkan strategi untuk mendukung prospek perdagangan rumput laut di Indonesia. $\mathrm{Hal}$ ini melihat tingginya permintaan, banyaknya produk turunan yang dapat dihasilkan dan potensi budidaya rumput laut yang besar di Indonesia.

\section{TINJAUAN PUSTAKA}

\section{Budidaya Rumput Laut di Indonesia}

Jenis rumput laut yang paling banyak di budidayakan di Indonesia adalah Euchema cottonii dan Gracilaria sp. E. cottonii dibudidayakan di laut atau air asin sedangkan Gracilaria sp. dibudidayakan di tambak atau air tawar. Menurut Astruli (Asosiasi Industri Rumput Laut Indonesia), produksi rumput laut Indonesia tahun 2017 mencapai 974.064 ton rumput laut kering. Pada tahun 2018, Astruli mencatat produksi rumput laut kering melalui bahan baku yang dibeli oleh industri mencapai 84.934 ton rumput laut kering jenis E. cottonii dan 51.641 ton rumput laut kering jenis Gracilaria sp. (Tabel 2).

Tabel 2. Produksi rumput laut di Indonesia

\begin{tabular}{|c|l|c|}
\hline No & Jenis Rumput Laut & Produksi (ton kering) \\
\hline 1 & E. cottonii & 84.934 \\
\hline 2 & Gracilaria sp. & 51.641 \\
\hline
\end{tabular}

Persebaran potensi budidaya rumput laut ditunjukkan oleh Gambar 4. Dari data tersebut terlihat bahwa Provinsi Papua Barat memiliki luas potensi areal budidaya rumput laut terbesar, disusul oleh Sulawesi Selatan dan Maluku. Umumnya budidaya $E$. cottonii menggunakan teknik tali (long line) dan apung (Priono 2013). Sedangkan budidaya Gracilaria sp. umumnya dilakukan dengan metode dasar (bibit diletakkan di dasar perairan) bersamaan dengan lokasi budidaya udang windu atau udang vaname dan ikan bandeng. Budidaya Gracilaria sp. dengan udang windu dan ikan bandeng dapat ditemui pada tambak di Sidoarjo, Jawa Timur dan budidaya Gracilaria sp. dengan ikan bandeng saja dapat ditemui pada tambak di Karawang, Jawa Barat.

\section{Industri Rumput Laut di Indonesia}

Industri rumput laut di Indonesia dalam pembahasan ini difokuskan pada industri pengolahan produk setengah jadi. Produk setengah jadi atau produk antara rumput laut adalah produk yang digunakan sebagai bahan baku industri lain (Hikmah 2015). Produk setengah jadi rumput laut meliputi ATC, ATG, tepung agar dan tepung karaginan. Jumlah industri yang menghasilkan produk setengah jadi ini mencapai 79 industri (Astruli 2018). Persebaran dari industri ini diantaranya digambarkan pada Gambar 5. Pembeli yang ingin membeli produk setengah jadi rumput laut Indonesia bisa mengunjungi situs www.indonesianseaweed.com. Situs tersebut merupakan platfom berkumpulnya industri rumput laut Indonesia. Faktanya selain industri pegolahan produk setengah jadi, di Indonesia juga banyak perusahaan yang hanya menjual rumput laut kering. Jawa Timur sebagai provinsi dengan jumlah pabrik rumput laut terbanyak melalui data dari Dinas Kelautan dan Perikanan (DKP) (2018) menunjukkan bahwa 16 dari 37 jumlah industri rumput laut di Jawa Timur menghasilkan produk rumput laut kering (Gambar 6 dan Tabel 3). Rumput laut kering ini nantinya akan dipasok ke industri dalam negeri atau di ekspor sebagai bahan baku mentah. 


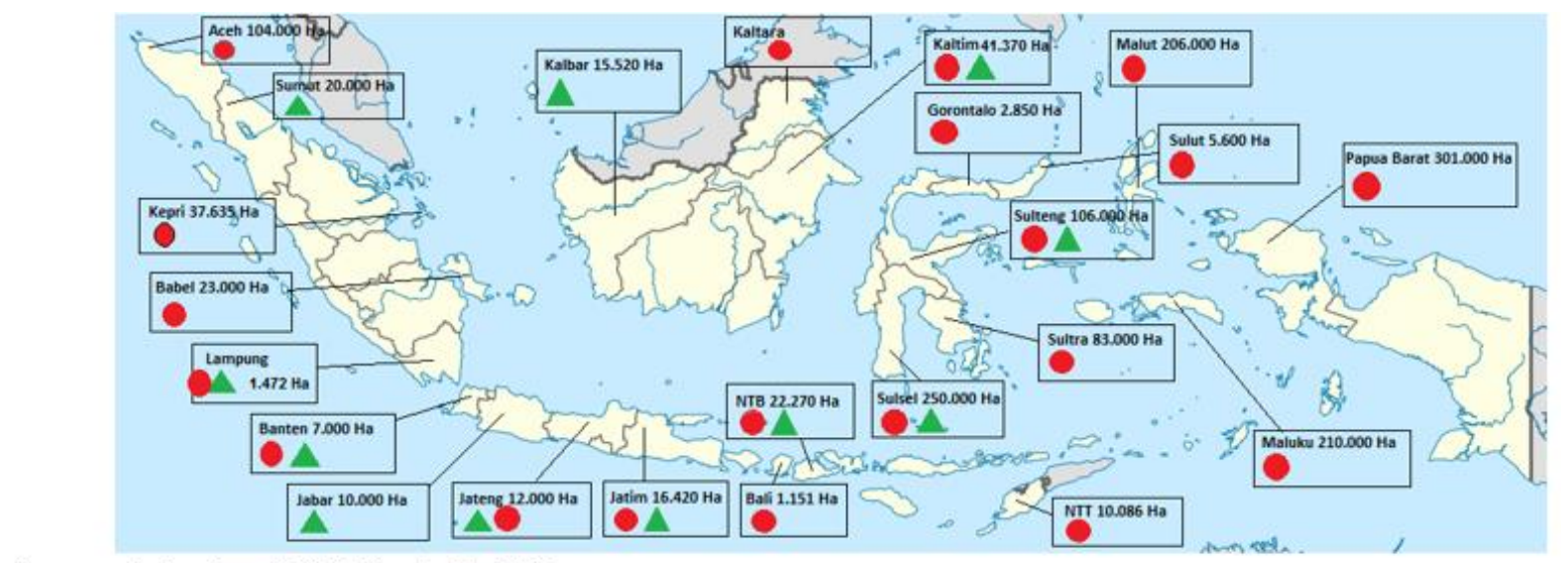

Keterangan: Sumber: Kemen KP (diolah Kemenko Ekon), 2016

Eucheuma sp., A Grocilorio sp.

Gambar 4. Potensi budidaya rumput laut di Indonesia

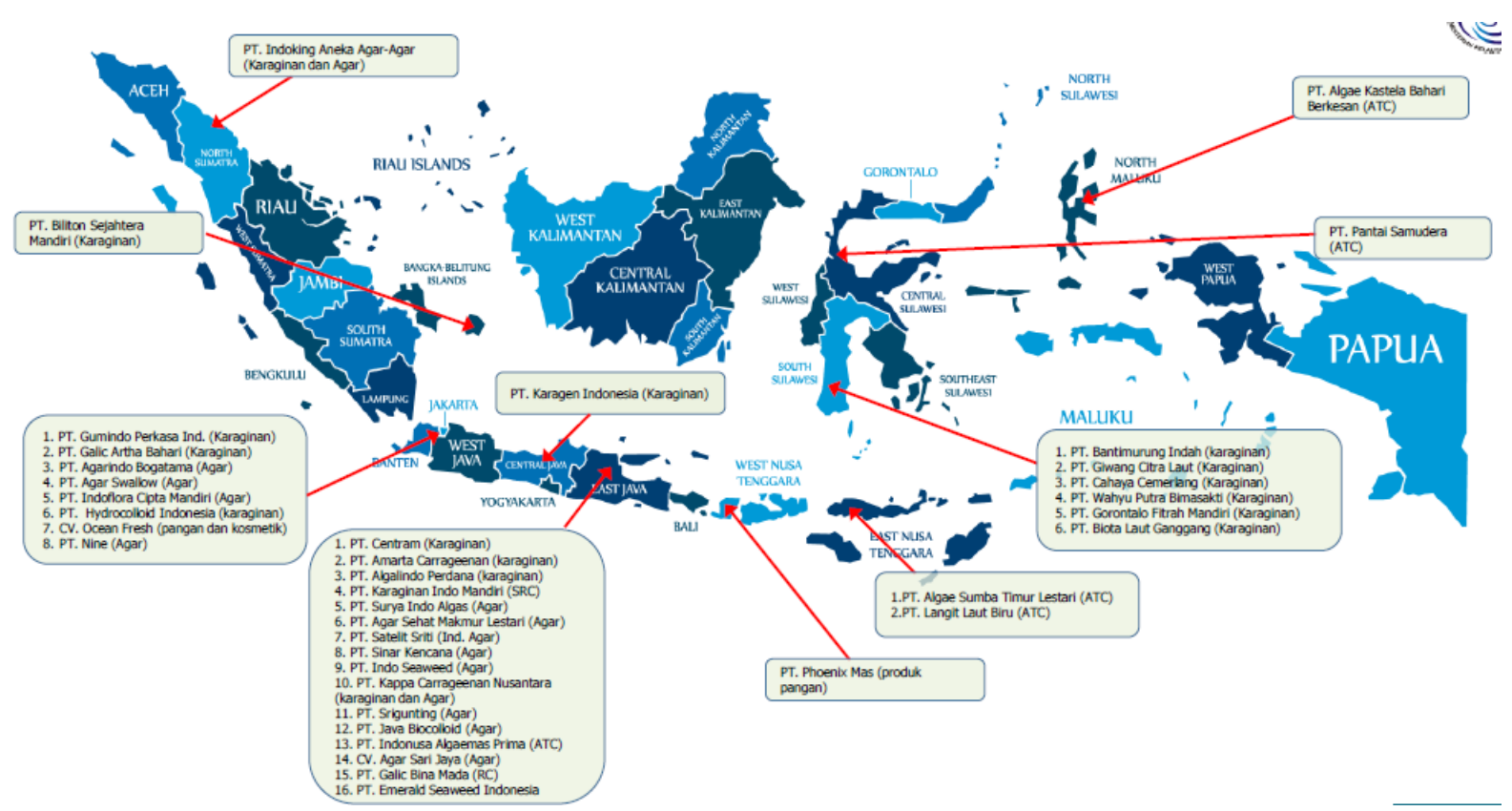

Gambar 5. Persebaran industri rumput laut di Indonesia

Tabel 2. Persebaran industri rumput laut di Jawa Timur

\begin{tabular}{|l|l|l|}
\hline No & \multicolumn{1}{|c|}{ Nama Perusahaan } & \multicolumn{1}{|c|}{ Produk } \\
\hline 1 & $\begin{array}{l}\text { CV Bahana Cipta } \\
\text { Mandiri }\end{array}$ & $\begin{array}{l}\text { Rumput laut } \\
\text { kering }\end{array}$ \\
\hline 2 & $\begin{array}{l}\text { Bina Makmur } \\
\text { Sejahtera, UD }\end{array}$ & $\begin{array}{l}\text { Rumput laut } \\
\text { kering }\end{array}$ \\
\hline 3 & $\begin{array}{l}\text { PT Buana Tunas } \\
\text { Segara Subur }\end{array}$ & $\begin{array}{l}\text { Rumput laut } \\
\text { kering }\end{array}$ \\
\hline 4 & CV Bumi Raya Indah & $\begin{array}{l}\text { Rumput laut } \\
\text { kering }\end{array}$ \\
\hline 5 & CV Indomarin Niaga & $\begin{array}{l}\text { Rumput laut } \\
\text { kering }\end{array}$ \\
\hline 6 & $\begin{array}{l}\text { PT Jaya Laut } \\
\text { Internasional }\end{array}$ & $\begin{array}{l}\text { Rumput laut } \\
\text { kering }\end{array}$ \\
\hline 7 & $\begin{array}{l}\text { PT Jendidah Agro } \\
\text { Trading }\end{array}$ & $\begin{array}{l}\text { Rumput laut } \\
\text { kering }\end{array}$ \\
\hline
\end{tabular}

\begin{tabular}{|l|l|l|}
\hline No & Nama Perusahaan & \multicolumn{1}{|c|}{ Produk } \\
\hline 8 & $\begin{array}{l}\text { CV Lingga Inti } \\
\text { Persada }\end{array}$ & $\begin{array}{l}\text { Rumput laut } \\
\text { kering }\end{array}$ \\
\hline 9 & CV Multi Indotama & $\begin{array}{l}\text { Rumput laut } \\
\text { kering }\end{array}$ \\
\hline 10 & $\begin{array}{l}\text { PT Prima Agung } \\
\text { Sejahtera }\end{array}$ & $\begin{array}{l}\text { Rumput laut } \\
\text { kering }\end{array}$ \\
\hline 11 & $\begin{array}{l}\text { PT Rula Lautan } \\
\text { Nusantara }\end{array}$ & $\begin{array}{l}\text { Rumput laut } \\
\text { kering }\end{array}$ \\
\hline 12 & $\begin{array}{l}\text { PT Sinas Kentjana } \\
\text { Surabaya }\end{array}$ & $\begin{array}{l}\text { Rumput laut } \\
\text { kering, tepung } \\
\text { agar-agar }\end{array}$ \\
\hline 13 & UD Rahmat Bahari & $\begin{array}{l}\text { Rumput laut } \\
\text { kering }\end{array}$ \\
\hline 14 & PT Satelit Sriti & $\begin{array}{l}\text { Tepung agar- } \\
\text { agar }\end{array}$ \\
\hline 15 & PT Amarta & Tepung \\
\hline
\end{tabular}




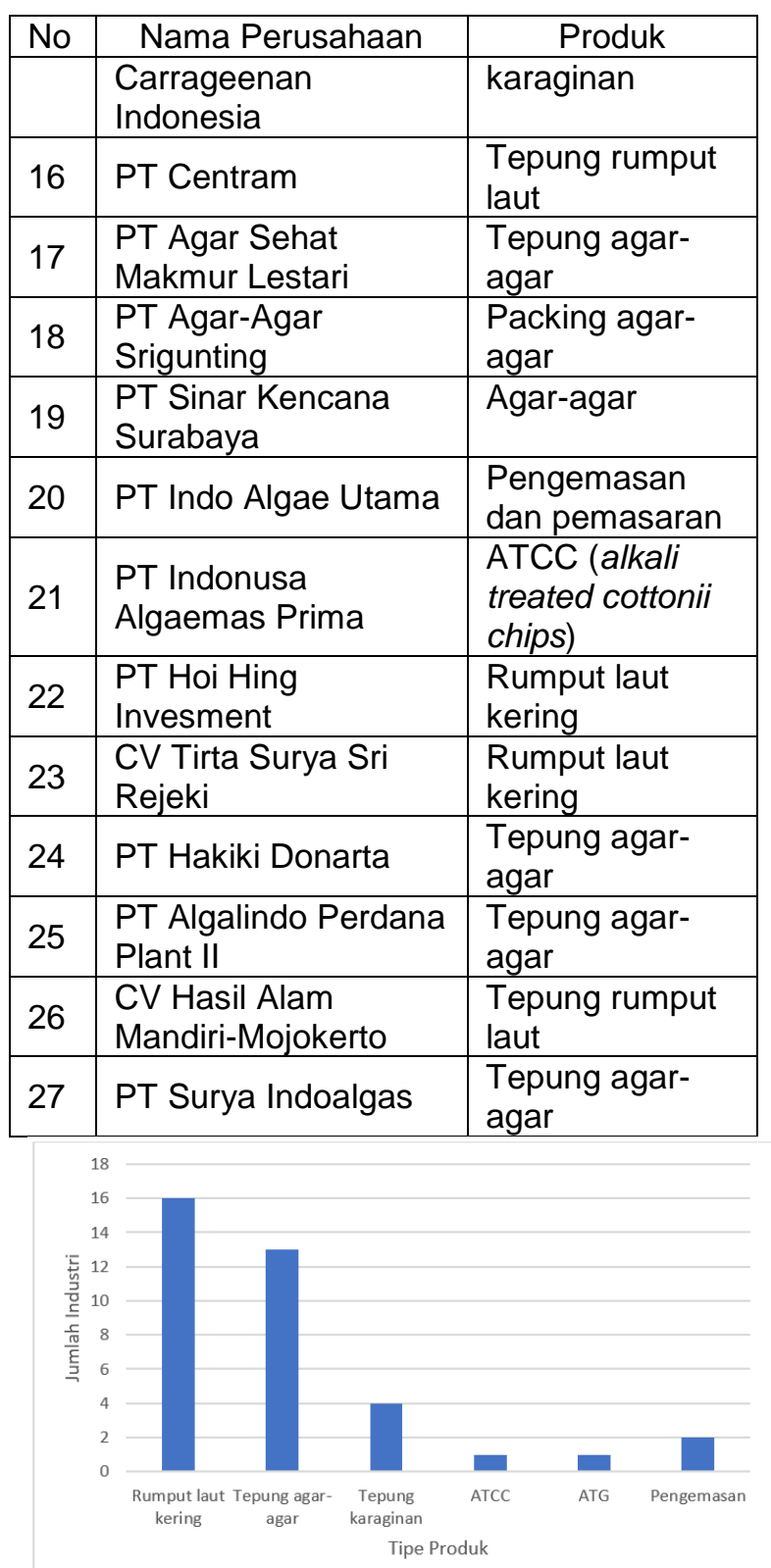

Gambar 6. Sebaran tipe produk industri rumput laut di Jawa Timur

\section{Kebijakan Pemerintah Indonesia mengenai Rumput Laut}

Pemerintah melalui Peraturan Presiden (Perpres) telah mengusun Perpres Nomor 33 Tahun 2019 tentang Peta Panduan (Road Map) Pengembangan Industri Rumput Laut Nasional Tahun 2018-2021. Pada Perpres tersebut dijelaskan tentang perdagangan rumput laut, pengembangan budidaya, pengembangan industri, penelitian pengembangan rumput laut, langkahlangkah strategis yang dilakukan kementerian/lembaga terkait rumput laut, tantangan dan permasalahan, peta

\begin{tabular}{|l|l|l|}
\hline No & Nama Perusahaan & \multicolumn{1}{|c|}{ Produk } \\
\hline 28 & $\begin{array}{l}\text { CV Sari Mutiara } \\
\text { Abadi }\end{array}$ & $\begin{array}{l}\text { Tepung agar- } \\
\text { agar }\end{array}$ \\
\hline 29 & CV Agar Sari Jaya & $\begin{array}{l}\text { Tepung agar- } \\
\text { agar }\end{array}$ \\
\hline 30 & $\begin{array}{l}\text { PT Bestagar } \\
\text { Pureindo } \\
\text { Internasional }\end{array}$ & $\begin{array}{l}\text { ATG (alkali } \\
\text { treated } \\
\text { gracilaria) }\end{array}$ \\
\hline 31 & $\begin{array}{l}\text { CV Carrageenan Indo } \\
\text { Mandiri }\end{array}$ & $\begin{array}{l}\text { Tepung agar- } \\
\text { agar }\end{array}$ \\
\hline 32 & $\begin{array}{l}\text { PT Gemilang Mulia } \\
\text { Lestari }\end{array}$ & $\begin{array}{l}\text { Tepung } \\
\text { karaginan }\end{array}$ \\
\hline 33 & $\begin{array}{l}\text { PT Bumi Indojaya } \\
\text { Gemilang }\end{array}$ & $\begin{array}{l}\text { Rumput laut } \\
\text { kering }\end{array}$ \\
\hline 34 & $\begin{array}{l}\text { PT Kappa } \\
\text { Carrageenan } \\
\text { Nusantara }\end{array}$ & $\begin{array}{l}\text { Tepung agar- } \\
\text { agar dan refined } \\
\text { carrageenan }\end{array}$ \\
\hline 35 & PT Indo Seawed & $\begin{array}{l}\text { Tepung agar- } \\
\text { agar }\end{array}$ \\
\hline 36 & PT Java Biocolloid & $\begin{array}{l}\text { Tepung agar- } \\
\text { agar }\end{array}$ \\
\hline 37 & PT Galic Bina Mada & $\begin{array}{l}\text { Tepung refined } \\
\text { carrageenan }\end{array}$ \\
\hline 38 & $\begin{array}{l}\text { PT Emerald Seaweed } \\
\text { Indonesia }\end{array}$ & $\begin{array}{l}\text { Tepung agar- } \\
\text { agar }\end{array}$ \\
\hline
\end{tabular}

panduan, strategi, program, dan sasaran serta rencana aksi pengembangan industri rumput laut nasional. Hal yang dicermati dalam Perpres tersebut adalah target capaian pengembangan industri rumput laut (Gambar 7). Target capaian ini merupakan peluang yang bagus dalam melihat prospek perdagangan rumput laut di Indonesia. Capaian yang ditargetkan pada tahun 2019 adalah memenuhi kebutuhan semi refined carrageenan (SRC) dari produksi dalam negeri. Sehingga ini peluang untuk melakukan investasi pendirian pabrik SRC dan melakukan perdagangan SRC. Apalagi hal ini didukung oleh peningkatan pangsa pasar sebesar 5\%. Pada tahun 2020, pemerintah menargetkan Indonesia menguasai $10 \%$ pangsa pasar karaginan dunia dan komposisi ekspor rumput laut dan barang bernilai tambah menjadi $60 \%$ dan $40 \%$. Tentu hal ini merupakan hal positif untuk melakukan investasi dan perdagangan produk bernilai tambah berupa karaginan.

Selain Perpres Nomor 33 tahun 2019, Pemerintah juga mengeluarkan Undang-Undang (UU) Nomor 9 tahun 2011 tentang Sistem Resi Gudang. 
Menurut UU tersebut, Sistem resi gudang adalah kegiatan yang berkaitan dengan penerbitan, pengalihan, penjaminan, dan penyelesaian transaksi resi gudang. Resi gudang adalah dokumen bukti kepemilikan atas barang yang disimpan di gudang yang diterbitkan oleh pengelola gudang. Sistem resi gudang bertujuan untuk menjaga kestabilan harga bahan baku dengan cara petani dapat menitipkan barangnya ke gudang dan mengagunkan surat resi ke bank. Hal ini sangat berguna ketika terjadi panen raya yang mengakibatkan harga rumput laut kering menjadi turun. Dengan adanya sistem resi gudang, petani dapat menunda menjual rumput lautnya untuk mendapatkan harga yang lebih layak dan tetap bisa memiliki dana operasional dengan mengagunkan surat

resi.

\begin{tabular}{|c|c|c|c|}
\hline 2018 & 2019 & 2020 & 2021 \\
\hline $\begin{array}{l}\text { - Percepatan } \\
\text { peningkatan } \\
\text { kapasitas produksi } \\
\text { olahan industri } \\
\text { rumput laut } \\
\text { domestik; } \\
\text { - Operasionalisasi } \\
\text { pabrik baru } \\
\text { pengolahan } \\
\text { rumput laut } \\
\text { berdekatan dengan } \\
\text { sentra produksi } \\
\text { rumput laut; } \\
\text { Penumbuhan } \\
\text { wirausaha baru } \\
\text { industri kecil dan } \\
\text { menengah berbasis } \\
\text { rumput laut; } \\
\text { Penggunaan } \\
\text { rumput laut dalam } \\
\text { produk pangan } \\
\text { olahan tortilla; } \\
\text { Meningkatkan } \\
\text { kualitas data dan } \\
\text { sistem informasi } \\
\text { rumput laut; } \\
\text { Pendapatan } \\
\text { pembudidaya } \\
\text { rumput laut } \\
\text { meningkat minimal } \\
\text { sebesar } 5 \% \text { per } \\
\text { tahun. } \\
\end{array}$ & $\begin{array}{l}\text { - Memenuhi } \\
\text { kebutuhan Semi } \\
\text { Refined } \\
\text { Carrageenan (SRC) } \\
\text { dari produksi dalam } \\
\text { negeri; } \\
\text { - Peningkatan } \\
\text { investasi industri } \\
\text { rumput laut untuk } \\
\text { pemenuhan } \\
\text { kebutuhan dalam } \\
\text { negeri dan ekspor; } \\
\text { - Peningkatan pangsa } \\
\text { pasar sebesar } 5 \% \text {. }\end{array}$ & $\begin{array}{l}\text { - Mencanangkan } \\
\text { program 5P } \\
\text { (Pangan, Pakan, } \\
\text { Pupuk/ZPT, Produk } \\
\text { Farmasi, dan } \\
\text { Produk Kosmetik); } \\
\text { - Komposisi ekspor } \\
\text { rumput laut yaitu } \\
60 \% \text { bahan baku } \\
\text { dan 40\% barang } \\
\text { bernilai tambah } \\
\text { sedang dan tinggi; } \\
\text { - Menguasai di atas } \\
\text { 10\% pangsa pasar } \\
\text { karaginan dunia } \\
\text { melalui } \\
\text { peningkatan } \\
\text { kapasitas dan daya } \\
\text { saing; } \\
\text { Membentuk Badan } \\
\text { Pengelolaan Dana } \\
\text { Pengembangan } \\
\text { Rumput Laut. }\end{array}$ & $\begin{array}{l}\text { Menjadi market } \\
\text { leader dunia } \\
\text { untuk industri } \\
\text { karaginan (ATC } \\
\text { SRC) dan agar- } \\
\text { agar; } \\
\text { Mencapai } \\
\text { komposisi ekspor } \\
\text { minimum 50:50 } \\
\text { untuk barang jadi } \\
\text { dan bahan baku; } \\
\text { Mencapai 5\% } \\
\text { recommended mix } \\
\text { rumput laut } \\
\text { dalam pakan ikan } \\
\text { dan pakan ternak. }\end{array}$ \\
\hline
\end{tabular}

Gambar 7. Target capaian pengembangan industri rumput laut 


\section{METODOLOGI}

Penelitian ini dikerjakan dengan menggunakan pendekatan desk study dan dilakukan pada tahun 2019. Metode desk study adalah metode yang digunakan untuk mempelajari informasi, data dan laporan yang mempunyai relevansi dengan tujuan yang ingin dicapai (Hikmah 2015). Pengambilan data dilakukan dengan metode wawancara dan observasi lapang yang dilakukan dalam kurun waktu Januari - September 2019. Wawancara dilakukan terhadap stakeholder terkait, diantaranya dari Kementerian Perindustrian, Kementerian Perdagangan, Badan Koordinasi Penanaman Modal, Astruli, DKP Provinsi Jawa Timur.

Metode analisis data yang digunakan adalah metode deskriptif kualitatif. Metode deskriptif kualitatif digunakan untuk menggambarkan secara rinci fakta-fakta yang ditemui dilapangan dari wawancara mendalam (Linarwati et al. 2016). Selain itu, penelitian ini juga menggunakan analisis SWOT untuk menggambarkan prospek perdagangan rumput laut Indonesia.

\section{TAHAPAN PENELITIAN}

Penelitian ini dimulai dengan melakukan studi pustaka dan wawancara dengan narasumber terkait. Hasil studi pustaka dan wawancara menjadi dasar untuk penyusunan matrix SWOT dan perumusan strategi untuk mendukung prospek perdagangan rumput laut Indonesia. Tahapan penelitian diilustrasikan dalam Gambar 8.

\section{HASIL DAN PEMBAHASAN}

\section{Pengembangan Produk Setengah Jadi Rumput Laut}

Rumput laut Indonesia memiliki prospek untuk dinaikkan nilai tambahnya. Menurut Concon 2013, nilai tambah rumput laut kering menjadi refined carrageenan (RC) mencapai $674 \%$ (Tabel 3). RC dapat menjadi produk antara yang akan digunakan untuk industri-industri lainnya seperti industri makanan dan minuman, industri kosmetik dan industri toiletries. RC digunakan sebagai bahan pengental dalam industri tersebut.

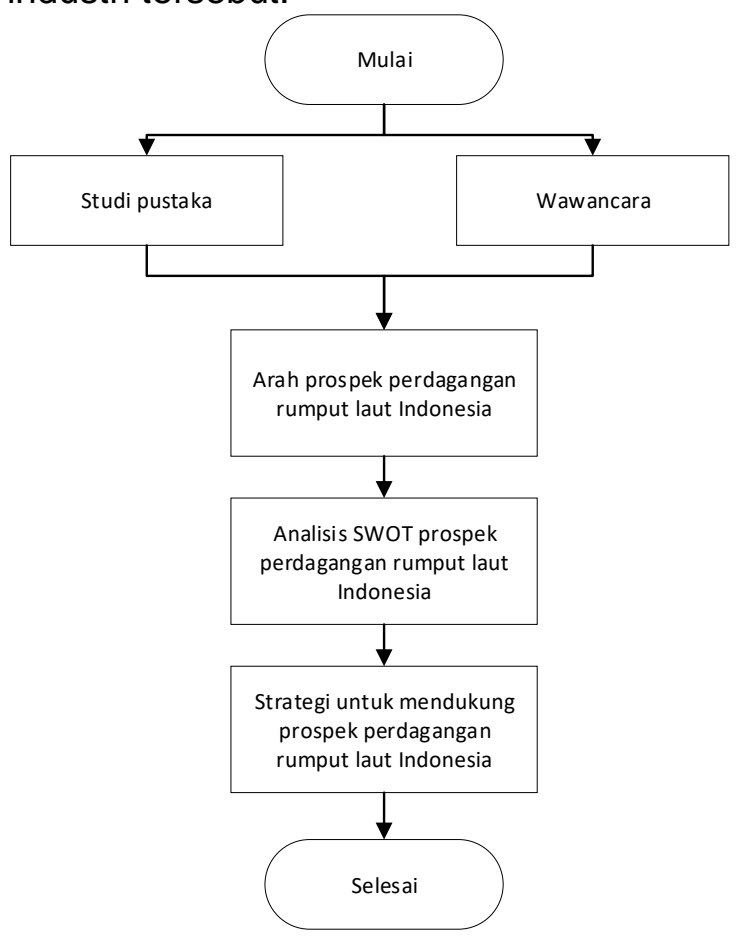

Gambar 8. Tahapan penelitian

Tabel 3. Nilai tambah produk rumput laut

\begin{tabular}{|l|l|c|c|}
\hline Produk & $\begin{array}{l}\text { Rendemen } \\
(\%)\end{array}$ & $\begin{array}{c}\text { Harga } \\
(\mathrm{Rp} / \mathrm{kg})\end{array}$ & $\begin{array}{c}\text { Nilai } \\
\text { Tambah } \\
(\%)\end{array}$ \\
\hline $\begin{array}{l}\text { Rumput } \\
\text { laut } \\
\text { kering }\end{array}$ & $\begin{array}{l}12 \% \text { dari } \\
\text { rumput laut } \\
\text { basah }\end{array}$ & 7.000 & - \\
\hline $\begin{array}{l}\text { ATC } \\
\text { chips }\end{array}$ & $\begin{array}{l}31,5 \% \text { dari } \\
\text { rumput laut } \\
\text { kering }\end{array}$ & 60.000 & 270 \\
\hline SRC & $\begin{array}{l}25 \% \text { dari } \\
\text { rumput laut } \\
\text { kering }\end{array}$ & 80.000 & 285 \\
\hline $\begin{array}{l}\text { Karagin } \\
\text { an } \\
\text { kertas }\end{array}$ & $\begin{array}{l}25 \% \text { dari } \\
\text { rumput laut } \\
\text { kering }\end{array}$ & 95.000 & 339 \\
\hline RC & $\begin{array}{l}23,6 \% \text { dari } \\
\text { rumput laut } \\
\text { kering }\end{array}$ & 200.000 & 674 \\
\hline
\end{tabular}

\section{Hasil Analisis SWOT Prospek} Perdagangan Rumput Laut Indonesia

Dari hasil wawancara yang dilakukan dengan narasumber terkait didapatkan, fakta-fakta yang menggambarkan prospek rumput laut Indonesia. Untuk lebih mudah memahami fakta-fakta ini, peneliti menyajikan dalam analisis SWOT. Analisis SWOT adalah sebuah metode untuk menganalisis 
kekuatan (strenght), kelemahan (weakness), peluang (opportunity) dan ancaman (threat) dari masalah yang dikaji (Irawan 2017).

Kekuatan rumput laut Indonesia meliputi:

- Potensi budidaya yang besar mencapai 1,43 juta ha

- Jumlah angkatan kerja mencapai 136,13 juta jiwa (BPS 2019)

- Konsumsi dalam negeri besar dengan jumlah penduduk mencapai 267 juta jiwa (Badan Perencanaan dan Pembangunan Nasional (Bappenas) (2018))

- Daerah budidaya rumput laut masih bagus, terutama di bagian timur Indonesia seperti Maluku dan Maluku Utara. Perariran yang bagus akan menghasilkan bobot rumput laut yang lebih besar

- Budidaya rumput laut tergolong mudah. Peralatan budidaya relatif murah dan mudah didapat sehingga biaya budidaya cenderung murah dengan biaya investasi Rp9.062.000 (Direktorat Usaha dan Investasi KKP 2017)

- Ketersediaan teknologi dan tenaga ahli pembangunan pabrik pengolahan rumput laut sudah memadai

Kelemahan rumput laut Indonesia meliputi:

- Pengetahuan sumber daya manusia khususnya petani yang masih rendah. Hal ini berdampak seringnya petani melakukan kecurangan, seperti panen yang lebih cepat dan rumput laut ditaburi garam agar bobotnya lebih tinggi

- Daerah budidaya rumput laut yang lebih banyak terdapat di pulau-pulau sehingga menyebabkan biaya transportasi lebih mahal dan lama

- Belum adanya mitigasi resiko kegagalan panen ditinggat petani. Petani sering mengalami gagal panen akibat curah hujan yang tidak menentu dan serangan virus

- Adanya ketidakstabilan harga bahan baku rumput laut sepanjang tahun mengakibatkan petani sering berlaku curang ketika harga rumput laut sedang tinggi
Peluang rumput laut Indonesia meliputi:

- Impor rumput laut dunia mencapai 530.553 ton pada tahun 2016. Hal ini merupakan peluang pasar yang sangat jelas

- Indonesia masih memiliki 81,24\% lahan yang potensial untuk menambah budidaya rumput laut

- Adanya road map yang jelas akan peran pemerintah dalam pengembangan rumput laut Indonesia

- Salah satu mandat road map adalah Indoesia membuka peluang investasi pengolahan rumput laut yang akan membuka pasar dan lapangan pekerjaan

- Adanya sistem resi gudang yang dapat membantu memberikan kemudahan bagi petani rumput laut

Ancaman rumput laut Indonesia meliputi:

- Kelangkaan atau kesulitan mencari bahan baku rumput laut jenis $E$. cottonii

- Harga rumput laut yang fluktuatif bahkan dititik tertinggi mencapai Rp24.000/kg untuk E. cottonii kering menyebabkan industri mulai mencari alternatif sumber hydrocolloid lain

- Pesaing dari negera lain seperti Filipina dan Spanyol

\section{Strategi Pendukung Prospek Rumput Laut Indonesia}

Tahap selanjutnya adalah merumuskan strategi berdasarkan analisis SWOT untuk mendukung prospek rumput laut Indonesia (Tabel 4). Strategi ini dibagi menjadi strategi SO, WO, ST dan WT. Strategi SO adalah strategi yang disusun dengan memanfaatkan kekuatan yang dimiliki untuk mengambil peluang yang tersedia. Strategi WO adalah strategi yang disusun untuk memanfaatkan peluang dalam rangka meminimumkan kelamahan yang dimiliki. Strategi ST adalah strategi yang disusun untuk memanfaatkan kekuatan dalam rangka menghindari ancaman yang ada. Strategi WT adalah strategi yang disusun untuk mengurangi kelemahan dalam rangka mencegah atau menghindari ancaman (Irawan 2017). 
Tabel 4. Strategi untuk mendukung prospek rumput laut Indonesia

\begin{tabular}{|c|c|c|}
\hline Faktor-Faktor & Kekuatan (Strenght) & Kelemahan (Weakness) \\
\hline $\begin{array}{l}\text { Peluang } \\
\text { (Opportunity) }\end{array}$ & $\begin{array}{l}\text { Strategi SO: } \\
\text { - Meningkatkan jumlah dan } \\
\text { kapasitas industri } \\
\text { pengolahan rumput laut } \\
\text { dalam negeri untuk dapat } \\
\text { mengambil pasar dunia } \\
\text { sebesar-besarnya. Produk } \\
\text { yang diutamakan adalah } \\
\text { produk setengah jadi } \\
\text { rumput laut } \\
\text { - Membangun iklim investasi } \\
\text { rumput laut yang sehat dan } \\
\text { menguntungkan } \\
\text { - Melakukan kerjasama } \\
\text { terintegrasi untuk } \\
\text { menambah areal budidaya } \\
\text { rumput laut di Indonesia. } \\
\text { Hal ini berguna untuk } \\
\text { mendukung peningkatan } \\
\text { jumlah dan kapasitas } \\
\text { industri pengolahan rumput } \\
\text { laut } \\
\text { - Menambah daerah-daerah } \\
\text { resi gudang untuk } \\
\text { menjamin bahan baku } \\
\text { rumput laut }\end{array}$ & $\begin{array}{l}\text { Strategi WO: } \\
\text { - Memberikan } \\
\text { pendampingan berjangka } \\
\text { panjang (minimal 3-5 } \\
\text { tahun) untuk meningkatkan } \\
\text { pengetahuan budidaya dan } \\
\text { manajemen yang baik } \\
\text { ditingkat petani rumput laut. } \\
\text { Hal ini untuk meningkatkan } \\
\text { daya saing petani dan } \\
\text { menjaga kualitas mutu } \\
\text { bahan baku } \\
\text { - Melakukan kerjasama } \\
\text { terintegrasi dalam hal } \\
\text { mengurangi biaya } \\
\text { transportasi laut } \\
\text { - Menciptakan sistem } \\
\text { informasi yang transparan, } \\
\text { adil dan terintegrasi untuk } \\
\text { mengetahui permintaan } \\
\text { dan penawaran bahan } \\
\text { baku. Hal berguna untuk } \\
\text { menjaga kestabilan harga } \\
\text { bahan baku dan mencegah } \\
\text { adanya mafia yang } \\
\text { mempermainkan harga }\end{array}$ \\
\hline $\begin{array}{l}\text { Ancaman } \\
\text { (Threat) }\end{array}$ & $\begin{array}{l}\text { Strategi ST: } \\
\text { - Menciptakan sistem } \\
\text { informasi yang transparan, } \\
\text { adil dan terintegrasi di tiap } \\
\text { daerah untuk mengetahui } \\
\text { produksi rumput laut } \\
\text { daerah tersebut. Hal ini } \\
\text { mempermudah melakukan } \\
\text { penelurusan bahan baku. } \\
\text { Sistem ini bisa diterapkan } \\
\text { dipelabuhan-pelabuhan } \\
\text { hasil perikanan } \\
\text { - Meningkatkan kampanye } \\
\text { rumput laut Indonesia } \\
\text { melalui kampanye } \\
\text { "Indonesian Seaweed". } \\
\text { Rumput laut Indonesia } \\
\text { yang terjaga mutu, harga } \\
\text { dan kontinuitasnya untuk } \\
\text { bisa bersaing dengan } \\
\text { rumput laut dari negara lain }\end{array}$ & $\begin{array}{l}\text { Strategi WT: } \\
\text { - Memberikan } \\
\text { pendampingan bagi petani } \\
\text { rumput laut untuk } \\
\text { meningkatkan pengetahuan } \\
\text { budidaya dan manajemen } \\
\text { yang baik } \\
\text { - Menciptakan sistem } \\
\text { informasi yang transparan, } \\
\text { adil dan terintegrasi untuk } \\
\text { mengetahui permintaan } \\
\text { dan penawaran agar } \\
\text { menjaga stabilitas harga } \\
\text { bahan baku }\end{array}$ \\
\hline
\end{tabular}




\section{SIMPULAN}

Dari analisis yang dilakukan dapat disimpulkan bahwa prospek rumput laut Indonesia masih sangat menjanjikan untuk fokus dikembangkan menjadi produk setengah jadi. Hal ini diketahui dari hasil analisis SWOT bahwa rumput laut Indonesia memiliki kekuatan berupa lahan potensi rumput yang masih banyak, jumlah angka kerja tinggi, konsumsi dalam negeri dan pasar dunia tinggi. Prospek ini didukung oleh peluang yang dapat diambil meliputi penambahan lahan budidaya, pasar impor yang besar, dan adanya dukungan positif pemerintah dari road map rumput laut meliputi sistem resi gudang dan iklim investasi. Namun rumput laut Indonesia memiliki kelemahan berupa pengetahuan petani yang kurang, harga bahan baku berfluktuatif, belum ada mitigasi kegagalan panen, dan tidak terintegrasinya informasi permintaan dan penawaran. Ancaman yang dimiliki rumput laut Indonesia meliputi kelangkaan atau kesulitan bahan baku dan pesaing dari negera lain. Strategi yang dapat dilakukan untuk mendukung prospek rumput laut di Indonesia meliputi strategi SO, WO, ST dan WT. Strategi SO: meningkatkan jumlah dan kapasitas industri pengolahan rumput laut (produk setengah jadi) dalam negeri, membangun iklim investasi rumput laut, dan menambah daerah-daerah resi gudang untuk menjamin bahan baku rumput laut. Strategi WO: memberikan pendampingan berjangka panjang (minimal 3-5 tahun) untuk meningkatkan pengetahuan budidaya dan manajemen yang baik ditingkat petani rumput laut, melakukan kerjasama terintegrasi dalam hal mengurangi biaya transportasi laut, dan menciptakan sistem informasi yang transparan, adil dan terintegrasi untuk mengetahui permintaan dan penawaran bahan baku. Strategi ST: menciptakan sistem informasi dan meningkatkan kampanye rumput laut. Strategi WT: menciptakan sistem informasi dan memberikan pendampingan bagi petani.

\section{DAFTAR PUSTAKA}

[Astruli] Asosiasi Industri Rumput Laut Indonesia. 2018. Kesiapan industri nasional dalam mengembangkan produk turunan rumput laut.

[Bappenas] Badan Perencanaan dan Pembangunan Nasional. 2018. Proyeksi Pertumbuhan Penduduk Indonesia 20102035.

[BPS] Badan Pusat Statistik. 2018. Ekspor rumput laut dan ganggang lainnya menurut negara tujuan utama.

[BPS] Badan Pusat Statistik. 2019. Februari 2019: Tingkat Pengangguran Terbuka (TPT) sebesar 5,01 persen.

Concon. 2013. Pendekatan Pembangunan Industri Rumput Laut Pada Sentral Produksi Budidaya. Diakses dari website: http://www.djpb.kkp.go.id pada 23 September 2019.

Direktorat Usaha dan Investasi dan Direktorat Jenderal Penguatan Daya Saing Produk Kelautan dan Perikanan Kementerian Kelautan dan Perikanan. 2017. Usaha Kelautan dan Perikanan Layak Investasi.

Hikmah. 2015. Strategi pengembangan industri pengolahan komoditas rumput laut E.cottonii untuk peningkatan nilai tambah di sentra kawasan industrialisasi. Jurnal Kebijakan Sosek KP. 5(1): pp. 27-36.

Irawan MRN. 2017. Analisis SWOT untuk menentukan strategi kompetitif pada PD. BPR. Bank daerah Lamongan. Jurnal Ekonomi Universitas Kadiri. 2(1): pp. 4056.

Linarwati M, Fathoni A, Minarsih MM. 2016. Studi deskriptif pelatihan dan pengembangan sumberdaya manusia serta penggunaan metode behavioral event interview dalam merekrut karyawan baru di Bank Mega cabang Kudus. Journal of Management. 2(2): pp. 1-8.

[KKP RI] Kementerian Kelautan dan Perikanan Republik Indonesia. 2017. Peraturan Menteri Kelautan Dan Perikanan Republik Indonesia Nomor 63/PERMENKP/2017 Rencana Strategis Kementerian Kelautan Dan Perikanan Tahun 2015 2019.

Priono B. 2013. Budidaya rumput laut dalam upaya peningkatan industrialisasi perikanan. Media Akuakultur. 8(1): pp. 18.

http://indonesianseaweed.com

[Perpres] Peraturan Presiden Republik Indonesia Nomor 33 tahun 2019 tentang Peta Panduan (Road Map) Pengembangan Industri Rumput Laut Nasional Tahun 2018-2021

[UU] Undang-Undang Nomor 9 tahun 2011 tentang Sistem Resi Gudang. 